\title{
PENGARUH SELF-REGULATED LEARNING DAN DUKUNGAN ORANG TUA TERHADAP HASIL BELAJAR PESERTA DIDIK PADA MATA PELAJARAN EKONOMI PROGRAM STUDI IPS SMA NEGERI DI KOTA JOMBANG
}

\author{
Sucipto, \\ suciptoadis@yahoo.com
}

\begin{abstract}
ABSTRAK
Penelitian ini bertujuan untuk mengetahui seberapa besar pengaruh selfregulated learning (SRL) dan dukungan orang tua terhadap hasil belajar peserta didik pada mata pelajaran ekonomi program studi IPS SMA Negeri di kota Jombang. Penelitian ini menggunakan pendekatan kuantitatif korelasional dengan subjek sebanyak 463 orang program studi IPS yang tergabung dari tiga sekolah yakni SMA Negeri 1 Jombang, SMA Negeri 2 Jombang, dan SMA Negeri 3 Jombang. Metode pengumpulan data menggunakan kuesioner, dokumentasi, dan wawancara. Teknik pengambilan sampel yakni menggunakan teknik random sampling. Teknik analisa data dengan menggunakan uji statistik regresi linear ganda. Hasil penelitian ini menunjukkan bahwa terdapat pengaruh yang signifikan antara self-regulated learning (SRL) dan dukungan orang tua terhadap hasil belajar peserta didik pada mata pelajaran ekonomi program studi IPS SMA Negeri di Jombang.
\end{abstract}

Kata kunci: Self-Regulated Learning, Dukungan Orang Tua, Hasil Belajar

\begin{abstract}
This research aims at knowing how broad the influence of self-regulated learning (SRL) and parents' support towards students' learning outcomes class social in economic subjects in State Senior High Schools in Jombang. This research used quantitative correlational approach which is done in three schools, they are SMA Negeri 1 Jombang, SMA Negeri 2 Jombang and SMA Negeri 3 Jombang in total of 463 social students as the subject. The data collection method in this research covers questionnaire, documentation, and interview. The sampling technique used random sampling technique. The data analysis technique used multiple linier regression statistical. The result of this research shows that there is significant influence between self-regulated learning (SRL) and parents' support towards students' achievement in economic subject social class in State Senior High Schools in Jombang.
\end{abstract}

Keywords: Self-Regulated Learning, Parent's Support, Learning outcomes

\section{PENDAHULUAN}

Penyelenggaraan pendidikan memberikan nilai positif bagi pengembangan kualitas Sumber Daya Manusia (SDM), karena tantangan global dan persaingan antar bangsa dalam berbagai aspek kehidupan terasa semakin kompetitif. Karena itu lahirnya SDM unggul dan perwujudan perkembangan anak berbakat intelektual secara optimal yang dapat bersaing dalam lingkup nasional dan lingkup internasional atau global harus dipercepat (Hawadi, 2006). 
Sistem pendidikan di Indonesia mengalami pengembangan secara terus menerus disetiap jenjang pendidikan, mulai dari Sekolah Dasar (SD) sampai pada Perguruan Tinggi (PT). Salah satunya adalah Sekolah Menengah Atas (SMA) yang merupakan salah satu tempat pendidikan untuk dapat mengembangkan kemampuan yang dimiliki individu baik dalam segi kognitif, afektif maupun psikomotor melalui proses pembelajaran yang dilakukan di sekolah. Hal tersebut diharapkan mampu menghasilkan generasi-generasi muda yang cerdas, kreatif, cekatan dan bertanggung jawab. Piaget memaparkan, masa remaja merupakan masa perkembangan dalam aspek kognitif yang sudah mencapai taraf operasi formal, sehingga aktivitas peserta didik SMA merupakan hasil dari berfikir logis (Santrock, 2007). Selain itu aspek afektif dan moral remaja juga telah berkembang yang diharapkan mampu mendukung penyelesaian tugas-tugasnya. Pendapat tersebut menggambarkan bahwa peserta didik SMA dianggap telah mampu bertanggung jawab dalam penyelesaian berbagai tugas termasuk tugas akademik. Namun berdasarkan realita masih terdapat peserta didik SMA yang mengalami masalah dalam menjalankan tugas-tugas akademik.

Fenomena umum yang terjadi pada peserta didik saat ini adalah sebagian perilaku peserta didik remaja banyak menghabiskan waktu hanya untuk urusan hiburan semata dibandingkan dengan urusan akademik. Hal ini terlihat dari kebiasaan suka begadang, jalan-jalan di mall atau plaza, menonton televisi hingga berjam-jam, kecanduan game online dan suka menunda waktu pekerjaan (Savitri, 2011). Ketika seorang peserta didik tidak dapat memanfaatkan waktu dengan baik, sering mengulur waktu dengan melakukan kegiatan yang tidak bermanfaat sehingga waktu terbuang dengan sia-sia. Tugas terbengkalai dan penyelesaian tugas tidak maksimal berpotensi mengakibatkan kegagalan atau terhambatnya seorang peserta didik meraih kesuksesan. Kegagalan atau kesuksesan individu sebenarnya bukan karena faktor intelegensi semata namun peserta didik tidak mampu mengelola proses belajar individu sendiri melalui pengaturan dan pencapaian tujuan dengan mengacu pada metakognisi, serta perilaku aktif dalam belajar mandiri yang dikenal dengan istilah self-regulated learning (SRL).

Penelitian sebelumnya tentang self-regulated learning, menunjukkan bahwa self-regulated learning berhubungan dengan prestasi akademik. Misalnya penelitian yang dilakukan oleh; Siti dan Fatimah (2013) menemukan, bahwa kelompok mahasiswa yang diberikan pelatihan self-regulated learning (SRL) memiliki prestasi akademik lebih tinggi dibandingkan kelompok mahasiswa yang tidak diberi pelatihan self-regulated learning (SRL); Fitria dan Safira (2013) menemukan, bahwa peserta didik yang memiliki self-regulated learning (SRL)nya rendah akan diikuti prokrastinasi akademik yang tinggi, dan sebaliknya peserta didik yang self-regulated learning (SRL)nya tinggi akan diikuti prokrastinasi akademik yang rendah; Refista (2013) menemukan bahwa peserta didik yang memiliki self-regulated learning (SRL) yang tinggi diikuti dengan prestasi akademik yang tinggi pula begitu juga sebaliknya peserta didik yang memiliki self-regulated learning (SRL) yang rendah diikuti dengan prestasi akademik yang rendah. Eka Rahil (2013) juga menemukan bahwa peserta didik yang ingin mencapai tingkat prestasi tertinggi, motivasi berprestasi harus dimiliki secara utuh. Individu yang memiliki motivasi berprestasi tinggi selalu berusaha untuk mendapatkan hasil yang baik di setiap tugasnya, membuat sesuatu yang unik dan berusaha melakukan sesuatu yang lebih baik dari orang lain. Dengan 
demikian dapat disimpulkan bahwa individu akan memperoleh hasil yang baik, jika memiliki regulasi diri (Self-Regulated Learning) yang baik.

Hasil belajar secara akademik menurut perspektif kognitif sosial dipandang sebagai hubungan yang kompleks antara kemampuan individu, persepsi diri, penilaian terhadap tugas, harapan akan kesuksesan, strategi kognitif dan regulasi diri, gender, gaya pengasuhan, status sosioekonomi, kinerja dan sikap individu terhadap sekolah (Clemons, 2008). Hal ini menunjukkan bahwa hasil belajar secara akademik individu ditentukan oleh dua faktor, baik eksternal maupun internal. Faktor eksternal salah satunya adalah dukungan orang tua. Dukungan orang tua adalah interaksi yang dikembangkan oleh orang tua yang dicirikan oleh perawatan, kehangatan, persetujuan, dan berbagai perasaan positif orang tua terhadap anak (Ellis, Thomas \& Rollins dalam Lestari, 2012). Menurut Johnson dan Johnson (dalam Rambe \& Tarmidi, 2011) dukungan sosial merupakan keberadaan orang lain yang dapat diandalkan untuk dimintai bantuan, dorongan dan penerimaan apabila individu mengalami kesulitan. Hidayati, (2011) menyebutkan bentuk-bentuk dukungan sosial orang tua, yaitu dukungan emosional berupa cinta dan kasih sayang, ungkapan empati, perlindungan, perhatian dan kepercayaan, keterbukaan serta kerelaan dalam memecahkan masalah seseorang. Kemudian dukungan instrumental berupa bantuan uang, kesempatan, dan modifikasi lingkungan. Selain itu juga ada dukungan informasi berupa pemberian nasehat, arahan, pertimbangan tentang bagaimana seseorang harus berbuat. Serta dukungan penilaian berupa pemberian penghargaan atas usaha yang telah dilakukan, memberikan umpan balik, mengenai hasil atau prestasi yang diambil individu.

Dukungan orang tua merupakan komponen penting dalam pendidikan anak. Hal ini menuntut adanya kontak secara langsung yang dapat diwujudkan dalam bentuk dukungan orang tua pada anaknya. Orang tua yang memberikan dukungan pada anaknya dalam belajar akan mampu meningkatkan semangat anak agar dapat belajar lebih giat, belajar dengan sungguh - sungguh, dan tidak mudah putus asa jika menghadapi kesulitan dalam belajar (Hasbulloh, 2010). Hal ini diperkuat oleh penelitian Jane, et al (2013), yang menemukan bahwa terdapat korelasi antara dukungan orang tua dengan motivasi belajar pada anak usia sekolah. Hal ini berarti semakin positif dukungan orang tua terhadap anak, maka semakin tinggi pula motivasi belajar pada anak.

Dari penjelasan di atas penelitian ini bertujuan untuk menganalisis pengaruh self-regulated learning dan dukungan orang tua terhadap hasil belajar peserta didik pada mata pelajaran ekonomi program studi IPS SMA Negeri di kota Jombang.

\section{Self-Regulated Learning (SRL)}

Menurut Zimmerman (2004), Self-regulated learning adalah sebuah konsep mengenai bagaimana individu menjadi regulator atau pengatur bagi dirinya sendiri. Woolfolk, (2008) mengatakan bahwa self-regulated learning merupakan sebuah proses dimana individu mengaktifan, kognisi, perilaku dan perasaanya secara sistematis dan mampu berorientasi pada pencapaian tujuan.

Menurut Schunk dan Zimmerman (2003), self regulated learning dapat berlangsung apabila individu secara sistematis mengarahkan perilakunya dan kognisinya dengan cara mempertanggungjawabkan tugas-tugas, menginterpre- 
tasikan pengetahuan, mengulang-ulang informasi untuk mengingatnya serta mengembangkan kemampuan belajar dan mengantisipasi hasil belajarnya. Selain itu Schunk dan Zimmerman (2003), menegaskan bahwa individu yang memiliki self regulated learning adalah secara metakognisi, motivasional, dan behavioral ikut aktif dalam proses belajar. Individu sengan sendirinya memulai belajar secara langsung untuk memperoleh pengetahuan dan keahlian yang diinginkan tanpa bergantung pada dosen, orang tua, dan orang lain.

Cobb (2003), mendefinisikan self regulated learning sebagai kemampuan menjadi individu yang aktif dalam proses pembelajaran ditinjau dari sudut metakognitif, motivasi dan perilaku. Dari sudut metakognitif, individu yang mandiri merencanakan, menentukan tujuan, mengatur, memonitor diri, dan mengevaluasi diri terhadap berbagai hal selama proses memperoleh keahlian. Dari sudut motivasi, individu yang mandiri menyadari kompetensinya, memperlihatkan keyakinan yang tinggi terhadap dirinya (High self-eficacy), dan ketertarikan pada tugas. Individu yang memiliki motivasi tinggi, memulai belajar dengan menampilkan usaha yang luar biasa dan tekun selama belajar. Dari segi perilaku, individu yang mandiri memilih, menyusun, dan menciptakan lingkungan mereka untuk bisa belajar optimal.

Pintrich dan Groot (2004) memberi istilah self regulation dalam belajar sebagai self regulated learning. Menurutnya, dalam self regulated learning terdapat tiga komponen self regulation, yaitu komponen 1. strategi-strategi kognitif, 2. strategi-strategi metakognitif dan 3. manajemen usaha. Menurut mereka, strategi-strategi kognitif adalah strategi-strategi yang digunakan untuk mengolah informasi seperti, pengulangan (rehearsal), elaborasi (elaboration), dan organisasi (organization), dan strategi-strategi metakognitif terdiri dari perencanaan (panning), pemantauan (monitoring), dan modifikasi kognitif (cognitive modification). Manajeman usaha adalah kegiatan individu mengelola dan mengontrol usaha mereka dalam menghadapi hambatan ketika menyelesaikan tugas-tugas akademis di kelas.

Selain ketiga komponen tesebut, menurut mereka masih diperlukan juga komponen lainnya, yaitu komponen motivational. Komponen ini memungkinkan peningkatan kemampuan motivational intrinsik individu dalam belajar. Komponen ini terdiri dari komponen harapan, yaitu keyakinan tentang dirinya, bahwa ia mampu menghadapi tugas-tugas tersebut sehingga akan lebih termotivasi untuk belajar (komponen self efficacy), komponen nilai yaitu komponen nilai-nilai intrinsik (intristic values) dan komponen afeksi, yaitu komponen-komponen menghadapi tes dan tugas-tugas (test anxiety).

Berdasarkan uraian pengertian-pengertian tersebut dapat ditarik kesimpulan, bahwa self regulated learning merupakan kemampuan dimana individu aktif dengan sengaja mengontrol proses kognitif, motivasi (keyakinan-keyakinan, nilainilai dan kondisi emosi) dan perilaku untuk mencapai tujuan tertentu yang telah diterapkan. Jadi dapat dikatakan bahwa semakin baik Self-Regulated Learning, maka akan semakin baik hasil prestasi yang dapat dicapai. Sebaliknya, jika peserta didik memiliki Self-Regulated Learning yang rendah, maka kurang dapat melakukan perencanaan, pemantauan, evaluasi pembelajaran dengan baik, kurang mampu melakukan pengelolaan potensi dan sumber daya yang baik dan sebagainya, sehingga hasil dari belajarnya tidak optimal, sesuai dengan potensi diri yang dimilikinya, Zimmerman (2004). 


\section{Dukungan Orang Tua}

Orang tua adalah orang yang pertama dan utama yang bertanggung jawab terhadap kelangsungan hidup dan pendidikan anaknya (Hasbulloh, 2010: 39). Oleh karena itu, sebagai orang tua harus dapat membantu dan mendukung terhadap segala usaha yang dilakukan oleh anaknya serta dapat memberikan pendidikan informal guna membantu pertumbuhan dan perkembangan anak tersebut serta untuk mengikuti atau melanjutkan pendidikan pada program pendidikan formal di sekolah. Bentuk dan isi serta cara-cara pendidikan dalam keluarga akan selalu mempengaruhi pertumbuhan dan perkembangan watak, budi pekerti dan kepribadian tiap-tiap manusia. Pendidikan yang diterima dalam keluarga inilah yang akan dicontoh oleh anak sebagai dasar yang digunakan untuk mengikuti pendidikan selanjutnya di sekolah.

Mengingat pendidikan anak ditanggung jawab oleh keluarga dalam pendidikan informalnya dan pendidikan formal ditanggung oleh sekolah, maka orang tua harus berperan dalam menanamkan sikap dan nilai hidup, mengembangkan bakat dan minat serta pembinaan bakat dan kepribadian. Selain itu, orang tua juga harus memikirkan dan memperhatikan sekolah anaknya, yaitu dengan memperhatikan pengalaman-pengalamannya dan menghargai segala usahanya serta harus dapat menunjukan kerjasamanya dalam mengarahkan cara anak belajar di rumah, membuat pekerjaan rumahnya, tidak menyita anak dengan melakukan pekerjaan rumah tangga, orang tua harus berusaha memotivasi dan membimbing anak dalam belajar. Pada dasarnya dukungan orang tua terhadap pendidikan anaknya menyangkut dua hal pokok yaitu dukungan moral dan dukungan material. Dukungan moral dari orang tua terhadap pendidikan anaknya dapat berupa perhatian terhadap pemenuhan kebutuhan piskis yang meliputi perhatian dari orang tua, bimbingan dan pengarahan, dorongan, menanamkan rasa percaya diri. Dengan perhatian orang tua yang berupa pemenuhan kebutuhan piskis tersebut diharapkan dapat memberikan semangat belajar anak guna meraih suatu cita-cita atau prestasi. Menurut Hasbulloh (2010: 60), selain dukungan moral dari orang tua terhadap kelangsungan pendidikan anaknya, ada juga dukungan dari orang tua yang berupa dukungan material. Dimana dukungan ini berupa pemenuhan kebutuhan fisik yaitu pengadaan fasilitas dirumah, pemenuhan kebutuhan belajar, dan keadaan ekonomi orang tua. Untuk memenuhi kebutuhan fisik tersebut tentunya berkaitan dengan status sosial ekonomi keluarga atau pendapatan di dalam keluarga itu sendiri.

\section{Hasil Belajar}

Hasil belajar seringkali digunakan sebagai ukuran untuk mengetahui seberapa jauh seseorang menguasai bahan yang sudah diajarkan. Hasil belajar dapat dijelaskan dengan memahami dua kata yang membentuknya, yaitu "hasil" dan "belajar" pengertian hasil (produk) menunjuk pada suatu perolehan akibat dilakukannya suatu aktifitas atau proses yang mengakibatkan berubahnya input secara fungsional. Dalam siklus input-proses-hasil, hasil dapat dengan jelas dibedakan dengan input akibat perubahan proses. Proses adalah kegiatan yang dilakukan oleh peserta didik dalam mencapai tujuan pengajaran. Menurut Djamarah (2002: 25) Hasil Belajar diartikan sebagai hasil akhir pengambilan keputusan tentang tinggi rendahnya nilai peserta didik selama mengikuti proses 
belajar mengajar, pembelajaran dikatakan berhasil jika tingkat pengetahuan peserta didik bertambah dari hasil sebelumnya.

Dimyati dan Mudjiono (2009:250-251), mengatakan bahwa "Hasil belajar merupakan hal yang dapat dipandang dari dua sisi yaitu sisi peserta didik dan sisi guru. Dari sisi peserta didik, hasil belajar merupakan tingkat perkembangan mental yang lebih baik bila dibandingkan pada saat sebelum belajar". Tingkat perkembangan mental tersebut terwujud pada jenis-jenis ranah kognitif, afektif dan psikomotorik. Sedangkan dari sisi guru hasil belajar merupakan saat terselesaikannya bahan pelajaran.

Menurut Hamalik (2006:30), hasil belajar adalah bila seseorang telah belajar akan terjadi perubahan tingkah laku pada orang tersebut, misalnya dari yang tidak tahu menjadi tahu, dari yang tidak mengerti menjadi mengerti. Menurut Sudjana (2012: 22), hasil belajar adalah kemampuan-kemampuan yang dimiliki peserta didik setelah ia menerima pengalaman belajar. Sedangkan menurut Tu'u (2004:75) hasil belajar lazimnya ditunjukkan dengan nilai tes angka atau nilai yang diberikan guru tertuang dalam bentuk skor yang diperolah anak di sekolah. Skor yang diperoleh tersebut biasanya dimasukkan ke dalam bentuk laporan yang disebut nilai ulangan harian dan rapor.

Berdasarkan pendapat beberapa ahli tersebut, maka dapat disintesiskan bahwa yang dimaksud dengan hasil belajar merupakan suatu penilaian akhir dari proses dan pengenalan yang telah dilakukan berulang-ulang, serta akan tersimpan dalam jangka waktu lama atau bahkan tidak akan hilang selama-lamanya karena hasil belajar akan turut serta membentuk pribadi individu yang selalu ingin mencapai hasil yang lebih baik, sehingga akan membawa perubahan perilaku yang terjadi setelah mengikuti proses belajar mengajar sesuai dengan tujuan pendidikan.

\section{METODE PENELITIAN}

Penelitian ini menggunakan pendekatan kuantitatif dengan menggambarkan regresi linier berganda antara dua variabel bebas dan variabel terikat. Dalam penelitian ini, variabel terikat yaitu hasil belajar $(\mathrm{Y})$ dan variabel bebasnya yaitu Self-Regulated Learning $\left(\mathrm{X}_{1}\right)$ dan dukungan orang tua $\left(\mathrm{X}_{2}\right)$. Populasi dalam penelitian ini adalah seluruh peserta didik program studi IPS SMA Negeri di Kota Jombang yang berjumlah 989 orang. Dengan rincian populasi SMA Negeri 1 Jombang sebanyak 396 orang, SMA Negeri 2 Jombang sebanyak 236 orang, dan SMA Negeri 3 Jombang sebanyak 357 orang Tahun Pelajaran 2013/2014. Sampel dalam penelitian ini adalah seluruh peserta didik program studi IPS SMA Negeri di Kota Jombang yang diambil dengan teknik random sampling. Sehingga sampel yang digunakan berjumlah 463 orang dengan taraf kesalahan 10\%. Dengan rincian sampel SMA Negeri 1 Jombang sebanyak 171 orang, SMA Negeri 2 Jombang sebanyak 130 orang, dan SMA Negeri 3 Jombang sebanyak 162 orang.

\section{Instrumen dan Pengumpulan Data}

Instrumen yang digunakan dalam penelitian ini yaitu Self-Regulated Learning yang diukur dengan menggunakan skala likert pada kisi-kisi kuesioner berdasarkan grand theory Zimmerman (2004) dimana 20 item yang terdiri dari 7 item pernyataan indikator metakognisi, 7 item pernyataan indikator motivasi, dan 
6 item pernyataan indikator perilaku. Dukungan orang tua diukur dengan menggunakan skala likert pada kisi-kisi kuesioner berdasarkan grand theory Hasbulloh (2010) dimana 20 item yang terdiri dari 10 item pernyataan indikator dukungan moral dan 10 item pernyataan indikator dukungan material. Sedangkan hasil belajar diukur berdasarkan hasil rata-rata nilai ulangan harian (UH), Ujian Tengah Semeter (UTS) dan Ujian Akhir Sekolah (UAS) semester ganjil. Metode pengumpulan data yang digunakan yaitu dengan metode kuesioner, dokumentasi, dan wawancara.

\section{Analisa Data}

Teknik analisa data menggunakan analisis regresi berganda, yaitu untuk mengetahui besarnya pengaruh Self-Regulated Learning dan dukungan orang tua terhadap hasil belajar peserta didik pada mata pelajaran ekonomi. Adapun persamaan regresi linier berganda adalah sebagai berikut:

Keterangan :

$$
\mathbf{Y}=\mathbf{a}+\mathbf{b}_{1} \mathbf{X}_{1}+\mathbf{b}_{2} \mathbf{X}_{2}+\mathbf{e}
$$

$\mathrm{Y} \quad=$ variabel terikat (Hasil belajar peserta didik)

$\mathrm{X}_{1} \quad=$ variabel bebas I (Self-Regulated Learning $)$

$\mathrm{X}_{2} \quad=$ variabel bebas II (Dukungan orang tua)

a $\quad=$ konstanta

$\mathrm{b}_{1, \mathrm{~b}_{2}}=$ koefisien regresi

e $\quad=$ error

Analisis data uji statistik yaitu uji $\mathrm{F}$ dan uji t. uji $\mathrm{F}$ digunakan untuk menguji signifikasi besarnya pengaruh variabel Self-Regulated Learning dan dukungan orang tua secara simultan terhadap hasil belajar peserta didik pada mata pelajaran ekonomi. Uji t digunakan untuk menguji signifikasi besarnya pengaruh variabel variabel Self-Regulated Learning dan dukungan orang tua secara parsial terhadap hasil belajar peserta didik pada mata pelajaran ekonomi.

\section{HASIL PENELITIAN DAN PEMBAHASAN}

Bagian ini untuk mengetahui tinggi rendahnya self-regulated learning dan dukungan orang tua. Untuk mengetahui tinggi rendahnya dilakukan pengelompokan data menjadi 5 kategori yaitu sangat tinggi, tinggi, cukup, rendah, dan sangat rendah.

\section{Distribusi Frekuensi Variabel Penelitian Self-Regulated Learning}

Berdasarkan hasil distribusi frekuensi data penelitian indikator metakognisi, maka diperoleh data bahwa SMA Negeri 1 Jombang memiliki metakognisi sebesar 3,61 dalam kategori tinggi, SMA Negeri 2 Jombang memiliki metakognisi sebesar 3,56 dalam kategori tinggi, dan SMA Negeri 3 Jombang memiliki metakognisi sebesar 3,68 dalam kategori tinggi, dan indikator motivasi maka diperoleh data bahwa SMA Negeri 1 Jombang memiliki motivasi sebesar 3,17 dalam kategori cukup, SMA Negeri 2 Jombang memiliki motivasi sebesar 3,59 dalam kategori tinggi, dan SMA Negeri 3 Jombang memiliki motivasi sebesar 3,76 dalam kategori tinggi sedangkan indikator perilaku, maka diperoleh data bahwa SMA Negeri 1 Jombang memiliki perilaku sebesar 3,40 dalam kategori cukup, SMA Negeri 2 Jombang memiliki perilaku sebesar 3,39 dalam 
kategori cukup, dan SMA Negeri 3 Jombang memiliki perilaku sebesar 3,73 dalam kategori tinggi.

\section{Distribusi Frekuensi Variabel Penelitian Dukungan Orang Tua}

Berdasarkan hasil distribusi frekuensi data penelitian indikator dukungan moral, maka diperoleh data bahwa SMA Negeri 1 Jombang memiliki dukungan moral sebesar 3,38 dalam kategori cukup, SMA Negeri 2 Jombang memiliki dukungan moral sebesar 3,37 dalam kategori cukup, dan SMA Negeri 3 Jombang memiliki dukungan moral sebesar 3,63 dalam kategori tinggi. Sedangkan frekuensi indikator dukungan material, maka diperoleh data bahwa SMA Negeri 1 Jombang memiliki dukungan material sebesar 3,33 dalam kategori cukup, SMA Negeri 2 Jombang memiliki dukungan material sebesar 3,50 dalam kategori tinggi, dan SMA Negeri 3 Jombang memiliki dukungan material sebesar 3,44 dalam kategori tinggi.

\section{Distribusi Frekuensi Variabel Hasil Belajar}

Berdasarkan data penelitian, maka diperoleh data bahwa SMA Negeri 1 Jombang memiliki rata-rata hasil belajar sebesar 80.92 dalam kategori baik, SMA Negeri 2 Jombang memiliki rata-rata hasil belajar sebesar 81.97 dalam kategori baik, dan SMA Negeri 3 Jombang memiliki rata-rata hasil belajar sebesar 84.10 dalam kategori baik.

\section{Uji Signifikan}

a. Persamaan regresi linier berganda

Model regresi yang diperoleh berdasarkan hasil penelitian, dapat dituliskan dalam bentuk persamaan sebagai berikut:

1) Persamaan regresi linier berganda pada Ulangan Harian

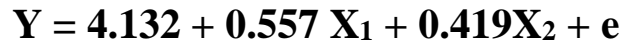

Dari persamaan regresi linier linier berganda dapat dijelaskan:

b. Konstanta $(\alpha)$ sebesar 4.132 artinya bahwa dengan menganggap semua variabel bebas sama dengan 0 , maka hasil belajar ulangan harian peserta didik pada mata pelajaran ekonomi program studi IPS SMA Negeri di Kota Jombang dalam kondisi positif dengan nilai 4.132 .

c. Koefisien self-regulated learning $\left(b_{1}\right)$ sebesar 0,557 artinya bahwa setiap perubahan satu persen self-regulated learning peserta didik pada mata pelajaran ekonomi program studi IPS SMA Negeri di Kota Jombang, maka hasil belajar ulangan harian peserta didik pada mata pelajaran ekonomi program studi IPS SMA Negeri di Kota Jombang akan mengalami peningkatan sebesar 0,557 persen. Dalam hal ini faktor lain yang mempengaruhi hasil belajar ulangan harian peserta didik pada mata pelajaran ekonomi program studi IPS SMA Negeri di Kota Jombang dianggap tetap.

d. Koefisien regresi dukungan orang tua $\left(b_{2}\right)$ sebesar 0,419 artinya bahwa setiap perubahan satu persen dukungan orang tua pada peserta didik pada mata pelajaran ekonomi program studi IPS SMA Negeri di Kota Jombang, maka hasil belajar ulangan harian peserta didik pada mata pelajaran ekonomi program studi IPS SMA Negeri di Kota 
Jombang akan mengalami peningkatan sebesar 0,419 persen. Dalam hal ini faktor lain yang mempengaruhi hasil belajar ulangan harian peserta didik pada mata pelajaran ekonomi program studi IPS SMA Negeri di Kota Jombang dianggap tetap.

2) Persamaan regresi linier berganda pada Ujian Tengah Semester

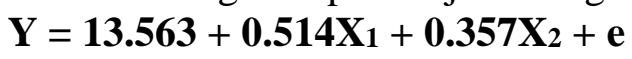

Dari persamaan regresi linier linier berganda dapat dijelaskan:

a. Konstanta $(\alpha)$ sebesar 13.563 artinya bahwa dengan menganggap semua variabel bebas sama dengan 0 , maka hasil belajar ujian tengah semester peserta didik pada mata pelajaran ekonomi program studi IPS SMA Negeri di Kota Jombang dalam kondisi positif dengan nilai 13.563 .

b. Koefisien self-regulated learning $\left(b_{1}\right)$ sebesar 0,514 artinya bahwa setiap perubahan satu persen self-regulated learning peserta didik pada mata pelajaran ekonomi program studi IPS SMA Negeri di Kota Jombang, maka hasil belajar ujian tengah semester peserta didik pada mata pelajaran ekonomi program studi IPS SMA Negeri di Kota Jombang akan mengalami peningkatan sebesar 0,514 persen. Dalam hal ini faktor lain yang mempengaruhi hasil belajar ujian tengah semester peserta didik pada mata pelajaran ekonomi program studi IPS SMA Negeri di Kota Jombang dianggap tetap.

c. Koefisien regresi dukungan orang tua $\left(b_{2}\right)$ sebesar 0,357 artinya bahwa setiap perubahan satu persen dukungan orang tua peserta didik pada mata pelajaran ekonomi program studi IPS SMA Negeri di Kota Jombang, maka hasil belajar ujian tengah semester peserta didik pada mata pelajaran ekonomi program studi IPS SMA Negeri di Kota Jombang akan mengalami peningkatan sebesar 0,357 persen. Dalam hal ini faktor lain yang mempengaruhi hasil belajar ujian tengah semester peserta didik pada mata pelajaran ekonomi program studi IPS SMA Negeri di Kota Jombang dianggap tetap.

3) Persamaan regresi linier berganda pada Ujian Akhir Sekolah

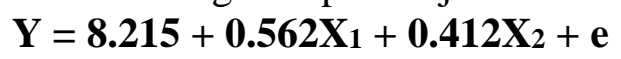

Dari persamaan regresi linier linier berganda dapat dijelaskan :

a. Konstanta $(\alpha)$ sebesar 8.215 artinya bahwa dengan menganggap semua variabel bebas sama dengan 0, maka hasil belajar ujian akhir sekolah peserta didik pada mata pelajaran ekonomi program studi IPS SMA Negeri di Kota Jombang dalam kondisi positif dengan nilai 8.215 .

b. Koefisien self-regulated learning $\left(b_{1}\right)$ sebesar 0,562 artinya bahwa setiap perubahan satu persen self-regulated learning peserta didik program studi IPS SMA Negeri di Kota Jombang, maka hasil belajar ujian akhir sekolah peserta didik program studi IPS SMA Negeri di Kota Jombang akan mengalami peningkatan sebesar 0,514 persen. Dalam hal ini faktor lain yang mempengaruhi hasil belajar ujian akhir sekolah peserta didik program studi IPS SMA Negeri di Kota Jombang dianggap tetap.

c. Koefisien regresi dukungan orang tua $\left(b_{2}\right)$ sebesar 0,412 artinya bahwa setiap perubahan satu persen dukungan orang tua peserta didik 
pada mata pelajaran ekonomi program studi IPS SMA Negeri di Kota Jombang, maka hasil belajar ujian akhir sekolah peserta didik program studi IPS SMA Negeri di Kota Jombang akan mengalami peningkatan sebesar 0,412 persen. Dalam hal ini faktor lain yang mempengaruhi hasil belajar ujian akhir sekolah peserta didik program studi IPS SMA Negeri di Kota Jombang dianggap tetap.

b. Uji F (Uji Serentak) dan Nilai Koefisien Determinasi

1) Hasil Uji F (Uji Serentak) dan Nilai Koefisien Determinasi UH

Hasil uji $\mathrm{F}$ berdasarkan uji statistik $\mathrm{F}$, diperoleh nilai $\mathrm{F}$ sebesar 982.739 dengan nilai signifikansi $\mathrm{p}=0,000$ lebih kecil dari 5\% sehingga dapat disimpulkan bahwa secara simultan (bersama-sama) variabel bebas self-regulated learning dan dukungan orang tua berpengaruh signifikan dan positif terhadap hasil belajar ulangan harian peserta didik pada mata pelajaran ekonomi program studi IPS SMA Negeri di Kota Jombang.

2) Hasil Uji F (Uji Serentak) dan Nilai Koefisien Determinasi UTS

Hasil uji $\mathrm{F}$ berdasarkan uji statistik $\mathrm{F}$, diperoleh nilai $\mathrm{F}$ sebesar 575.859 dengan nilai signifikansi $\mathrm{p}=0,000$ lebih kecil dari 5\% sehingga dapat disimpulkan bahwa secara simultan (bersama-sama) variabel bebas self-regulated learning dan dukungan orang tua berpengaruh signifikan dan positif terhadap hasil belajar ujian tengah semester (UTS) peserta didik pada mata pelajaran ekonomi program studi IPS SMA Negeri di Kota Jombang.

3) Hasil Uji F (Uji Serentak) dan Nilai Koefisien Determinasi UAS

Hasil uji $\mathrm{F}$ berdasarkan uji statistik $\mathrm{F}$, diperoleh nilai $\mathrm{F}$ sebesar 1005.857dengan nilai signifikansi $\mathrm{p}=0,000$ lebih kecil dari 5\% sehingga dapat disimpulkan bahwa secara simultan (bersama-sama) variabel bebas self-regulated learning dan dukungan orang tua berpengaruh signifikan dan positif terhadap hasil belajar ujian akhir (UAS) sekolah peserta didik pada mata pelajaran ekonomi program studi IPS SMA Negeri di Kota Jombang.

c. Uji t (Uji Individual)

1) Uji t (Uji Individual) Ulangan Harian (UH)

Nilai thitung pada variabel self-regulated learning sebesar 13.189 dengan tingkat signifikan kurang dari $5 \%$ yaitu 0,000 . Hal ini berarti selfregulated learning secara parsial berpengaruh signifikan pada hasil belajar ulangan harian.

Nilai thitung pada variabel dukungan orang tua sebesar 10.058 dengan tingkat signifikan kurang dari $5 \%$ yaitu 0,000 . Hal ini berarti dukungan orang tua secara parsial berpengaruh signifikan pada hasil belajar ulangan harian.

2) Uji t (Uji Individual) Ujian Tengah Semester (UTS)

Nilai thitung pada variabel self-regulated learning sebesar 10.442 dengan tingkat signifikan kurang dari 5\% yaitu 0,000. Hal ini berarti selfregulated learning secara parsial berpengaruh signifikan pada hasil belajar ujian tengah semester.

Nilai $t_{\text {hitung }}$ pada variabel dukungan orang tua sebesar 7.345 dengan tingkat signifikan kurang dari 5\% yaitu 0,000. Hal ini berarti dukungan 
orang tua secara parsial berpengaruh signifikan pada hasil belajar ujian tengah semester.

3) Uji t (Uji Individual) Ujian Akhir Sekolah (UAS)

Nilai thitung pada variabel self-regulated learning sebesar 13.757 dengan tingkat signifikan kurang dari 5\% yaitu 0,000. Hal ini berarti selfregulated learning secara parsial berpengaruh signifikan pada hasil belajar ujian tengah semester.

Nilai thitung pada variabel dukungan orang tua sebesar 10.019 dengan tingkat signifikan kurang dari 5\% yaitu 0,000. Hal ini berarti dukungan orang tua secara parsial berpengaruh signifikan pada hasil belajar ujian tengah semester.

Hasil tersebut diatas menunjukkan bahwa variabel self-regulated learning lebih dominan pengaruhnya terhadap hasil belajar dibandingkan dukungan orang tua.

\section{Pembahasan}

\section{Pengaruh Self-Regulated Learning Terhadap Hasil Belajar}

Berdasarkan analisis data diperoleh hasil yang menunjukkan bahwa selfregulated learning memiliki pengaruh yang signifikan terhadap hasil belajar peserta didik pada mata pelajaran ekonomi. Semakin tinggi self-regulated learning maka akan meningkatkan hasil belajar peserta didik.

Hasil penelitian ini mendukung penelitian sebelumnya yang telah dilakukan oleh Semra dan Ceren (2006) yang menunjukkan bahwa dengan strategi self-regulated learning maka peserta didik memiliki tingkat orientasi tujuan secara intrinsik, nilai tugas yang baik, penggunaan elaborasi belajar yang terstruktur, menjadikan peserta didik untuk berfikir kritis, memilki regulasi metakognisi yang baik, usaha yang dihasilkan terstruktur, dan belajar menggunakan dasar perbandingan. Begitu juga dengan penelitian Refista (2013), yang menunjukkan bahwa terdapat hubungan yang positif yang sangat signifikan antara self-regulated learning dengan prestasi akademik peserta didik. Semakin tinggi self-regulated learning yang dimiliki peserta didik, maka semakin tinggi pula prestasi akademik yang diperolehnya, begitu pula sebaliknya semakin rendah self-regulated learning yang dimiliki peserta didik, maka semakin rendah pula prestasi akademik yang diperoleh peserta didik.

Jadi berdasarkan teori Zimmerman (2004) menjelaskan self-regulated learning sebagai kemampuan peserta didik untuk berpartisipasi aktif dalam proses belajarnya, baik secara metakognitif, secara motivasional dan secara behavioral. Secara metakognitif peserta didik meregulasi diri dengan merencanakan, mengorganisasikan, menginstruksi diri, memonitor dan mengevaluasi dirinya dalam proses belajar. Secara motivasional, peserta didik merasa bahwa dirinya kompeten, memiliki keyakinan diri, dan memiliki kemandirian. Sedangkan secara behavioral, peserta didik menyeleksi, menyusun, dan menata lingkungan agar optimal dalam belajar. Ini berarti sesuai dengan hasil penelitian ini yang menerima hipotesis penelitian pertama.

\section{Pengaruh Dukungan Orang Tua Terhadap Hasil Belajar}

Penelitian ini mendukung hasil penelitian Hidayati (2011) yang menunjukkan bahwa dukungan orang tua berpengaruh terhadap hasil belajar peserta didik. Dukungan orang tua dapat berupa dukungan emosional berupa 
cinta dan kasih sayang, ungkapan empati, perlindungan, perhatian dan kepercayaan, keterbukaan serta kerelaan dalam memecahkan masalah anak yang berkaitan dengan masalah belajar dalam pendidikan. Kemudian bentuk dukungan instrumental berupa bantuan uang, kesempatan, dan modifikasi lingkungan. Hasil penelitian ini juga mendukung penelitian Jane et al (2013) menunjukkan bahwa terdapat hubungan antara dukungan orang tua dengan motivasi belajar pada anak usia sekolah. Hal ini berarti semakin positif dukungan orang tua terhadap anak, maka semakin tinggi pula motivasi belajar pada anak, sehingga secara tidak langsung akan berpengaruh terhadap hasil belajar anak. Dengan demikian hasil penelitian di atas sangat menguatkan penelitian ini dimana peserta didik program studi IPS SMA Negeri di kota Jombang memiliki nilai rata-rata ulangan harian, nilai rata-rata Ujian Tengah Semester (UTS), dan nilai rata-rata Ujian Akhir Sekolah (UAS) yang cenderung tinggi, hal ini menunjukkan bahwa dukungan orang tua peserta didik terhadap mata pelajaran ekonomi cenderung tinggi, baik secara moral maupun secara material.

Jadi sesuai dengan teori House \& Khan (dalam Hidayati, 2011) peran orang tua merupakan komponen penting dalam pendidikan anak. Orang tua yang memberikan dukungan pada anaknya dalam belajar akan mampu meningkatkan semangat anak agar dapat belajar lebih giat, belajar dengan sungguh-sungguh, dan tidak mudah putus asa jika menghadapi kesulitan dalam belajar. Hal ini diperkuat oleh penelitian Mindo (2008), yang menunjukkan bahwa ada korelasi positif antara dukungan orang tua dengan hasil belajar pada anak usia sekolah. Hal ini berarti semakin positif dukungan orang tua maka semakin tinggi hasil belajar, sebaliknya semakin negative dukungan orang tua maka semakin rendah pula hasil belajar yang diperoleh anak. Ini berarti sesuai dengan hasil penelitian ini yang menerima hipotesis penelitian kedua.

\section{Pengaruh Self-Regulated Learning dan Dukungan Orang Tua Terhadap} Hasil Belajar

Berdasarkan hasil penelitian ini menunjukkan bahwa self-regulated learning yang dimiliki SMA Negeri 1 Jombang, SMA Negeri 2 Jombang, dan SMA Negeri 3 Jombang berpengaruh besar terhadap hasil belajar ulangan harian yaitu sebesar 55,7\%, ujian tengah semester (UTS) sebesar 51,4\%, dan ujian akhir sekolah sebesar (UAS) 56,2\%. Hal ini disebabkan self-regulated learning yang dimiliki SMA Negeri 1 Jombang, SMA Negeri 2 Jombang, dan SMA Negeri 3 Jombang dalam kategori tinggi. Sedangkan dukungan orang tua peserta didik SMA Negeri 1 Jombang, SMA Negeri 2 Jombang, dan SMA Negeri 3 Jombang berpengaruh besar terhadap hasil belajar ulangan harian yaitu sebesar $41,9 \%$, ujian tengah semester (UTS) sebesar $35,7 \%$, dan ujian akhir sekolah sebesar (UAS) 41,2\%. Hal ini disebabkan dukungan orang tua yang dimiliki SMA Negeri 1 Jombang, SMA Negeri 2 Jombang, dan SMA Negeri 3 Jombang dalam kategori tinggi.

Berdasarkan teori Zimmerman (2004) Self-regulation of learning merupakan kegiatan memonitor dan mengontrol belajar diri peserta didik itu sendiri. Pengaturan belajar memiliki beberapa komponen, seperti motivasi, kepercayaan asal (epistemic) peserta didik, metakognisi, strategi belajar, dan pengetahuan sebelumnya (proir knowledge). Strategi belajar adalah aktifitas mental yang digunakan peserta didik ketika mereka belajar untuk membantu 
diri mereka sendiri dalam memperoleh, mengorganisasi, atau mengingat pengetahuan yang baru masuk yang lebih efisien. Menurut Zimmerman (2004), kategorisasi strategi belajar sebagai berikut:

a. Tambahan pengetahuan (knowledge acquisition) seperti analogis, yang membantu peserta didik mengorganisasi pengetahuan baru dan mengintegrasikannya dengan pengetahuan sebelumnya.

b. Monitoring menyeluruh (seperti praktek, yang membantu peserta didik mengetahui kapan mereka harus atau tidak belajar)

c. Strategi belajar aktif (seperti mencatat tugas, yang memungkinkan peserta didik membangun pengetahuan secara aktif dan partisipatori).

d. Strategi yang mendukung (seperti mengorganisasi meja yang akan menjadikan belajar kondusif).

Berdasarkan teori Hasbulloh (2010) dukungan orang tua dapat membantu dan mendukung terhadap segala usaha yang dilakukan oleh anak serta dapat memberikan pendidikan informal guna membantu pertumbuhan dan perkembangan anak tersebut untuk mengikuti atau melanjutkan pendidikan pada program pendidikan formal disekolah. Oleh karena itu, orang tua harus berperan dalam menanamkan sikap dan nilai hidup, mengembangkan bakat dan minat, serta pembinaan bakat kepribadian guna memperoleh hasil belajar yang optimal baik dukungan secara moral dan material.

Sesuai dengan teori-teori di atas, maka semakin menguatkan bahwa self-regulated learning dan dukungan orang tua memegang peranan penting dalam meningkatkan hasil belajar peserta didik program studi IPS SMA Negeri di Kota Jombang. Hal ini berarti sesuai dengan hasil penelitian.

\section{KESIMPULAN}

1. Self-Regulated Learning berpengaruh terhadap hasil belajar ekonomi peserta didik pada mata pelajaran ekonomi SMA Negeri di kota Jombang. Strategi self-regulated learning yang baik, maka dapat membantu dan melatih peserta didik untuk memusatkan perhatian dalam proses belajar mengajar, menentukan waktu dan menyelesaikan semua aktifitas yang terkait dengan tujuan belajar, mengarahkan pikiran dengan cara tidak menunda belajar, dan menentukan jadwal belajar khusus, sehingga tindakan dan perilaku peserta didik dapat mempengaruhi pilihan, usaha, dan ketekunan dalam menyelesaikan tugas akademis maupun non akademis.

2. Dukungan orang tua sangatlah penting dan berpengaruh terhadap hasil belajar peserta didik pada mata pelajaran ekonomi SMA Negeri di kota Jombang. Hal tersebut dapat dilakukan dengan cara mendampingi anak pada saat belajar, mengingatkan tugas anak, memeriksa hasil belajar yang diperoleh anak, memberikan suasana belajar yang nyaman, mengarahkan anak, dan memberikan penghargaan kepada anak sehingga hasil belajar yang dicapai anak bisa optimal. Hasil penelitian ini diharapkan dapat menjadi bahan masukan bagi sekolah-sekolah lain, meskipun mungkin tidak sepenuhnya akurat bila dterapkan karena situasi dan kondisi sekolah yang berbeda.

3. Self-Regulated Learning dan Dukungan orang tua berpengaruh terhadap hasil belajar peserta didik pada mata pelajaran ekonomi SMA Negeri di kota Jombang. Hal tersebut dapat dilihat dari hasil belajar nilai ulangan harian 
(UH), ujian tengah semester (UTS), dan ujian akhir sekolah (UAS) dengan kategori baik diatas nilai kriteria ketuntasan minimal yang ditentukan sekolah yaitu, sebesar 78 .

\section{DAFTAR RUJUKAN}

Clemons, T.L 2008. Underachieving gifted students: A social cognitive model. The National Research Centre on The Gifted and talented. Universutay of Virginia.

Cobb, R. J., 2003. The relationship between self-regulated learning behaviors and accademic performance in web-based course. Disertation, Virgina: Blacksburg.

Dimyati dan Mudjiono. 2009. Belajar dan Pembelajaran. Jakarta: PT Rineka Cipta.

Djamarah, S.B. 2002. Psikologi belajar. Jakarta: PT Rineka Cipta.

Fitria dan Yudi. 2013. Self Regulated Learning (SRL) Dengan Prokrastinasi Akademik Pada Siswa Akselerasi. Jurnal Ilmiah Psikologi Terapan Vol. 1, No 1.. Universitas Muhammadiyah Malang. Diunduh dari life_fitsav@rocketmail.com. Diakses pada tangga 3 September 2013.

Febrianela, Refista. 2013. Self Regulated Learning (SRL) Dengan Prestasi Akademik Siswa Akselerasi. Jurnal Ilmiah Psikologi Terapan Vol. 1, No 1. Universitas Muhammadiyah Malang. Diunduh dari http//www.ejournal.umm.ac.id. Diakses pada tangga 3 September 2013.

Hamalik, Oemar. 2006. Proses Belajar Mengajar. Jakarta: PT Bumi Karsa.

Hasbulloh. 2010. Dasar-dasar Ilmu Pendidikan. Jakarta: PT Raja Grafindo Persada.

Hawadi, Reni Akbar. 2006. A-Z Informasi Program Percepatan Belajar dan Anak Berbakat Intelektual. Jakarta: Erlangga.

Hidayati, S. 2011. Hubungan Dukungan Orang Tua Dengan Prestasi Belajar Siswa Kelas VII MTs ALMukarromin Wadak-Kidul Duduksampeyan Gresik. Diunduh dari http://lib.uinmalang.ac.id/thesis/chapter_ii/07410109-sucihidayati.ps. Diakses pada tanggal 4 September 2013.

Jane, Amatus, dan Abram .2013. Hubungan Antara Dukungan Orang Tua dengan Motivasi Belajar Pada Anak Usia Sekolah Kelas IV dan V Sekolah Dasar. Jurnal Keperawatan Vol 1, No 1. Universitas Sam Ratulangi Manado. Diunduh dari blue_cutez92@yahoo.co.id. Diakses pada tanggal 3

Lestari, S. 2012. Psikologi Keluarga: Penanaman Nilai dan Penanganan Konflik Dalam Keluarga. Jakarta: Kencana Prenada Media Group.

Mindo. R. R (2008). Hubungan Antara Dukungan Orang Tua Dengan Hasil Belajar Pada Anak Usia Sekolah Dasar. Diunduh dari: http//www.guadarma.ac.id/library/articles/graduate/phsycology/2008/ Art_ikel_10503225.pdf. Diakses pada tanggal 2 September 2013.

Pintrich, P.R \& De Groot, E.V. 2004. Motivational and Self-regulated learning component of classroom academic performance. Journal of Education Psychology,82,(1),33-40. Diunduh dari http//www.icmeganisers.dk/tsg20/leiss.pdf. Diakses pada tanggal 2 September 2013. 
Rahil, Eka. 2013. Motivasi Berprestasi dan Self Regulated Learning (SRL). Jurnal Ilmiah Psikologi Terapan Vol. 1, No 2. Universitas Muhammadiyah Malang. Diunduh dari http//www.ejournal.umm.ac.id. Diakses pada tangga 3 September 2013.

Rambe, A. R. R dan Tarmidi. 2011. Hubungan Antara Dukungan Sosial Orang Tua Dengan Kemandirian Belajar Pada Siswa Sekolah Menengah Atas. Diunduh dari http://repositori.usu.ac.id/bitstream/123456789/30170/4/Chapter\%2011.pdf. Diakses pada tanggal 28 Oktober 2013.

Santrock, W. J. 2007. Life span development: Perkembangan masa hidup (jilid 2). Jakarta : Erlangga.

Savitri, I. 2011. Arti belajar penting ditanamkan pada anak usia sekolah. LPTUI. Diunduh dari http://artikel.php.htm. Diakses 14 September 2013.

Siti dan Fatimah. 2013. Self Regulated Learning (SRL) Dalam Meningkatkan Prestasi Akademik Pada Mahasiswa. Jurnal Ilmiah Psikologi Terapan Vol. 1, No 1. Universitas Muhammadiyah Malang. Diunduh dari fasikhah@yahoo.com. Diakses pada tanggal 3 September 2013.

Sudjana, Nana. 2012. Penilain Hasil Proses Belajar Mengajar. Bandung: PT Remaja Rosdakarya.

Semra dan Ceren. 2006. Effects of Problem-Based Learning and Tradisional Instruction on Self Regulated Learning. Electronic Journal of Research in Educational Psychology, Vol. 2, No. 1. Diunduh Diunduh dari http//search.proquest.com. Diakses pada tanggal 3 September 2013.

Scunk, D. H \& Zimmerman, B.J. 2003. Self-regulated and Learning. In W.M. Reynolds \& G.E Miller (Eds), Handbook of psychology: Educational psychology (Vol. 7, pp. 59-78). Diunduh dari http// reviewofeducationalresearch.pdf. Diakses pada tanggal 1 Oktober 2013.

Tu'u, Tulus. 2004 .Peran Disiplin Pada Perilaku dan Prestasi Siswa. Jakarta: Grasindo.

Woolfolk, A. 2008. Educational paycohology active learning edition (terj. Helly P.J., \& Sri M. S 2009). Yogyakarta: Pustaka Pelajar.

Zimmerman, B.J. 2004. A social cognitive view of self- regulated academic learning. Journal of Educational Psychology, 4 (2), 22-63. Diunduh dari http://www.stu.ca/sbraat/SRL/A/Social0CognitiveViewofSelfRegulatedAca demicLearning.pdf. Diakses pada tanggal 2 September 2013. 